\title{
THE PROBLEMS OF IMPLEMENTATION OF FINANCIAL SERVICES AUTHORITY REGULATION NO. 11/POJK.03/2020 IN RELATION TO LEGAL AWARENESS AND LEGAL COMPLIANCE OF BANK MANDIRI MSME DEBTORS
}

\author{
Mompang Panggabean*, Benny Hutahayan** \\ *Fakultas Hukum, Universitas Kristen Indonesia, Jakarta \\ ** University Brawijaya, Malang, Jawa Timur \\ Corresponding author: gabean.mompang@gmail.com \\ Received on: 19-07-2021; Revised on: 28-08-2021; Approved to be published on: 06-09-2021; \\ DOI: http://dx.doi.org/10.30641/dejure.2021.V21.385-396
}

\begin{abstract}
The spread of Corona Virus Disease 2019 has disrupted the economy so that it has an impact on increased bank credit risk due to decreased performance and capacity of debtors in fulfilling credit or financing payment obligations. The Financial Services Authority (FSA) issued FSA Regulation No. 11/POJK.03/2020 concerning National Economic Stimulus as a Countercyclical Policy for the Impact of COVID-19 so that the pandemic does not have an impact on the domestic economy, including MSMEs. The goal is to provide credit relaxation for customers affected by Covid-19. This research aims to examine the effect of Legal Substance and Legal Awareness on the legal compliance of MSMEs as customers of Bank Mandiri. This research used a questionnaire as the research instrument. The questionnaire was used to measure the variables of Legal Substance, Legal Awareness and Legal Compliance. The data analysis used is the SEM GSCA approach using the GeSCA application. The results of the analysis showed that legal substance and legal awareness have a significant effect on legal compliance. The legal analysis of the substance of FSA Regulation Number 11/POJK.03/2020 in Indonesia for Bank Mandiri MSME debtors is the originality of this research.
\end{abstract}

Keywords: legal awareness; legal compliance; MSME; debtor

\section{INTRODUCTION}

In 2020, the world encountered a Corona Virus Disease 2019 (COVID-19) pandemic. The spread of COVID-19 brings risks to public health in various parts of the world, including Indonesia. The spread of Corona Virus Disease 2019 (COVID-19) has also significantly disrupted economic activities and has significant implications for the economy of several countries in the world, including Indonesia. The development of the COVID-19 pandemic also has the potential to disrupt economic activities in Indonesia. One of the implications is the decline in Indonesia's economic growth. The spread of this virus requires human activity to implement social distancing. At an extreme level, the government took a lockdown measure which resulted in a slowdown in economic activities (supply and demand). The government must recognize the risk of disruption to the economic sector that can occur at any time by mapping the potential of the affected sub-sectors and making appropriate policy alternatives.
The disruption of economic activities has implications for changes in the posture of the State Budget for Budget Year 2020, whether in terms of State Revenue, State Expenditure, and Financing. The State Budget comes from the state revenue sector. The implications of the Corona Virus Disease 2019 (COVID-19) pandemic also threaten to worsen the financial system as indicated by a decline in various domestic economic activities. Indirectly, measures to deal with the Corona Virus Disease 2019 (COVID-19) pandemic also have an impact on increased bank credit risk due to decreased performance and capacity of debtors in fulfilling credit or financing payment obligations, which has made various businesses gloomy so they have to get an attention because they have a central role in supporting the economy in Indonesia.

The Financial Services Authority (FSA) issued FSA Regulation Number 11/POJK.03/2020 concerning National Economic Stimulus as a Countercyclical Policy for the Impact of COVID-19 Disease. FSA has provided relaxation in the form of stimulus so that the pandemic does 
not have an impact on the domestic economy. Through this policy, banks have begun to aggressively restructure loans, providing relief to customers so that they do not turn into nonperforming loans.

According to Siti Nurhalimah ${ }^{1}$, credit facilities can provide benefits, but economic developments are influenced by global conditions which are full of uncertainty. Something that is expected to run smoothly can be hampered by certain conditions. At the beginning of 2020, the world was hit by the Corona Virus Disease 2019 (hereinafter referred to as COVID-19) which spread uncontrollably. In addition, since early March 2020 the COVID-19 pandemic has entered the territory of Indonesia.

Increased credit risk has the potential to disrupt banking performance and financial system stability that can affect economic growth, therefore countercyclical policy is needed. Countercyclical policy for the impact of the spread of the COVID-19 disease is aimed at encouraging banking performance, especially the intermediation function, maintaining financial system stability, and supporting economic growth. All of these is done by giving special treatment to credit or bank financing with a certain amount and restructuring credit or financing for affected debtors, including micro, small and medium enterprise debtors.

According to Dhevi Nayaari and Bambang Eko Muljono ${ }^{2}$, in an effort to keep banks in a healthy, liquid, solvent and profitable condition, the Financial Services Authority issued Financial Services Authority Regulation Number 11/ POJK.03/2020 concerning National Economic Stimulus as a Countercyclical Policy for the Impact of the Spread of Corona Virus Disease 2019 (hereinafter referred to as FSA Regulation No. 11/2020). After the enactment of the FSA Regulation No. 11/2020, according to Article 2 paragraph (1) and paragraph (2), it is true that Banks can implement policies that support

\footnotetext{
Siti Nurhalimah, 2020, Covid-19 Dan Hak Masyarakat Atas Kesehatan, SALAM: Jurnal Sosial dan Budaya Syar-i 7, no. 6, hlm 543-554.

2 Dhevi Nayasari Satradinata and Bambang Eko Muljono, 2020, Analisis Hukum Relaksasi Kreadit Saat Pandemi Corona Dengan Kelonggaran Kredit Berdasarkan Peraturan Otoritas Jasa Keuangan Nomor 11/POJK. 03/2020, Jurnal Sains Sosio Humaniora 4, no. 2, hlm 613-620.
}

economic stimulus growth for debtors affected by Covid-19 by doing so. Provisions regarding policy on asset quality and credit restructuring. Then, Article 5 paragraph (1) states that the quality of the restructured credit or financing is determined since the credit restructuring is carried out.

The parties bound in an agreement are also obliged to pay attention to the principles of the agreement, one of which is the existence of a deed of agreement that has been mutually agreed upon. In this case, it is hoped that the contents of the agreement are actually implemented by the parties, so that the objectives of the agreement can be achieved and fulfilled so that no party feels disadvantaged. In facing the Covid-19 outbreak, debtors must also have the awareness to pay installments that have become obligations if they are considered capable and do not experience difficulties in fulfilling their obligations to the Bank. So that the agreement that has been made is not hampered in its implementation. An agreement is a legal relationship that has legal consequences where the two parties who make the agreement have rights and obligations, and if one party does not fulfill these obligations, the other party can sue $^{3}$.

Clause 1132 of the Civil Code regulates possible exceptions from giving priority to other creditors. According to article 1133 of the Civil Code, prioritized creditors are those who have privileges, from pledges and from mortgages. The type of collateral held by a creditor affects the creditor's position ${ }^{4}$.

The current law enforcement is also no longer based on agreed values set by the government alone. To achieve clear legal objectives, the function of law enforcement has a strategic position. Law is a legal subsystem that does not stand alone, but is closely related to the situation that occurs in society. The process of law enforcement in society is expected to be fair and not harm other parties.

According to Marwah's previous research ${ }^{5}$, in this case, the Government in making new policies

\footnotetext{
3 Bambang Waluyo, 200o8, Penelitian Hukum Dalam Praktek, Jakarta, Sinar Gafika, hlm 79-8o.

4 R Wirjono Prodjodikoro, 2003, Asas-Asas Hukum Perjanjian, Mandar Maju, Bandung, vol. 3, hlm 3.

5 Marwah Marwah, 2019, Relaksasi Kredit Perbankan Di Daerah Wisata Yang Tertimpa Bencana Alama," Jurisprudentie: Jurusan Ilmu Hukum Fakultas Syariah dan Hukum 6, no. 1, hlm 125-134.
} 
in dealing with the Covid-19 outbreak is expected to provide clearer regulations and consider banking capacity. Debtors are also expected not to take advantage of this situation by not paying the installments that are their obligations to the bank. Debtors must also have the awareness to pay the installments that are due if they are capable and do not experience difficulties in fulfilling their obligations to the bank. Because in fact the Covid-19 outbreak has affected all sectors of the economy directly or indirectly.

The purpose of the issuance of this regulation is to provide credit relaxation for customers affected by Covid-19. However, the government did not further define the relaxation of bank credit in question. Even the government returned this definition to the policies of each bank. The legal definition of bank credit relaxation is the loosening of credit terms, both financial and non-financial, to facilitate banking customers.

The researchers have not found any research that examines the legal substance in relation to legal awareness and legal compliance. These three variables separately attracted the attention of some researchers, such as Adam Fletcher ${ }^{6}$ who researched the relaxation of bank credit. Biljana Macura $^{7}$ found that natural disasters can cause bad loans because the debtors are unable to pay the loan installments that have been agreed upon in an agreement. Meanwhile, Paul Schofield ${ }^{8}$ researched the relationship between public's legal awareness and driver fatigue on the road. Furthermore, Linda Klebe ${ }^{9}$ studied the awareness of local communities in complying with the law in protected forest areas and supporting the sustainable management of forest resources. Jared Hansen conducted research on the legal awareness of citizens in downloading music files without permission. One of research

6 Adam Fletcher et al., 2005, Countermeasures to Driver Fatigue: A Review of Public Awareness Campaigns and Legal Approaches, Australian and New Zealand Journal of Public Health 29, no. 5, hlm 471-476.

7 Biljana Macura et al., 2011, Local Community Attitudes toward Forests Outside Protected Areas in India. Impact of Legal Awareness, Trust, and Participation," Ecology and society 16, no. 3, hlm 6-7.

8 Paul Schofield, 2018, Following the Law Because It's the Law: Obedience, Bootstrapping, and Practical Reason, Philosophical Explorations 21, no. 3, 400-411.

9 Linda Klebe Treviño et al., 1999, Managing Ethics and Legal Compliance: What Works and What Hurts, California management review 41, no. 2 (1999), hlm 131-151. that studied compliance is the research of Paul Schofield entitled "Following the Law Because It's the Law: Obedience, Bootstrapping, and Practical Reason". Steven Klepper's research ${ }^{10}$ concludes that legal compliance is a person's attitude towards orders that must be obeyed and obligations that must be fulfilled. Kusumawati ${ }^{11}$ investigated what works and what disadvantages in ethical management and legal compliance. Ernawati's research ${ }^{12}$ is about the effect of taxpayer consultation with experts on legal compliance with tax regulations.

Based on the explanation of the research above, there is a gap in the literature that examines relaxation between the rule of law if it is associated with legal awareness and legal compliance. For this reason, it is necessary to study how the effect of loosening credit rules on legal awareness and legal compliance of debtors. The relaxation rules that will be discussed are the FSA Regulation No. 11/POJK.03/2020 concerning National Economic Stimulus as a Countercyclical Policy for the Impact of the Spread of Covid-19. This regulation relaxation is expected to reduce the impact of declining debtor performance, especially MSMEs, which can increase the risk of non-performing loans. Therefore, the researchers tried to examine what are the PROBLEMS OF IMPLEMENTATION OF FINANCIAL SERVICES AUTHORITY REGULATION NO. 11/POJK.03/2020 IN RELATION TO LEGAL AWARENESS AND COMPLIANCE OF BANK MANDIRI MSME DEBTORS. This is very interesting to study further because research on the relaxation of legal rules related to legal awareness and legal compliance of debtors in paying installments in the Covid-19 pandemic era

1o Steven Klepper, Mark Mazur, and Daniel Nagin, 1991, Expert Intermediaries and Legal Compliance: The Case of Tax Preparers, The Journal of Law and Economics 34, no. 1, hlm 205-229.

" Kusumastuti, N. R., \& Meiranto, W. (2012). Analisis faktor-faktor yang berpengaruh terhadap kecenderungan kecurangan akuntansi dengan perilaku tidak etis sebagai variabel intervening (Doctoral dissertation, Fakultas Ekonomika dan Bisnis)..

12 Ernawati, W. D., \& Purnomosidhi, B. (2011). Pengaruh sikap, norma subjektif, kontrol perilaku yang dipersepsikan dan sunset policy terhadap kepatuhan wajib pajak dengan niat sebagai variabel intervening. Peran dan Implementasi Statistika dalam Analisis Finansial dan Pengambilan Keputusan Bisnis, Semarang. 
has never been studied. This can be a novelty and contribution to legal science, especially business law.

\section{RESEARCH METHOD}

The research method used in this research is empirical legal research with a quantitative approach. This research measured and explored the relationship among several variables. The variables involved are the legal substance of the FSA Regulation Number 11 (X1), legal awareness (X2), and legal compliance (Y). The conceptual framework of this research can be seen in Figure 1.

Based on the research conceptual framework, the research hypotheses can be formulated as follows:

H1 : Legal Substance (X1) has a significant effect on Legal Compliance (Y)

H2: Legal Awareness (X2) has a significant effect on Legal Compliance (Y)

These three variables are reflected in several indicators. Each indicator was measured using several statement items. The complete indicators and items for each variable are presented in Table 1.

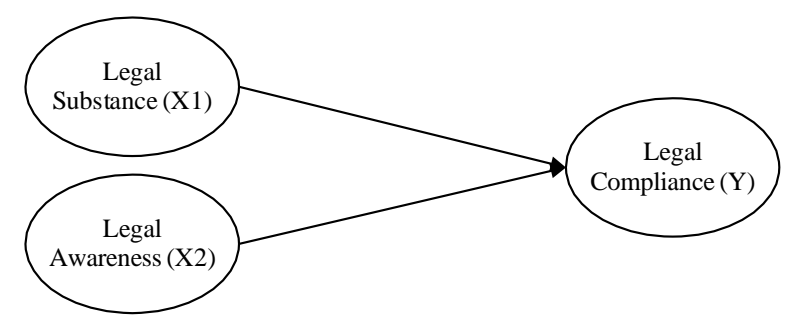

Figure 1. The Research Conceptual Framework

This research examined MSMEs which are Bank Mandiri debtors in the Special Region of Yogyakarta Province (DIY) and the Central Java Provincial Office by collecting primary data in the form of perceptions or assessments from respondents. Therefore, a survey was conducted by sending a questionnaire using a Google form to MSMEs which are debtors of Bank Mandiri as respondents. The population in this research is MSMEs which are debtors of Bank Mandiri. The sampling technique used is proportional random sampling. The number of samples was calculated using the Slovin formula, because the behavior of a population is not known with certainty and the population is large. The complete population and sample in this research are presented in Table 2.

Table 1. Variables, Indicators and Items ${ }^{13}$

\begin{tabular}{lll}
\hline Variables & Indicators & Items \\
\cline { 1 - 2 } & $\begin{array}{l}\text { Restructuring credit or financing } \\
\text { (X11) }\end{array}$ & 2 \\
Legal & Providing credit or financing (X12) & 2 \\
Substance & Providing other new funds (X13) & 2 \\
$(\mathrm{X} 1)$ & Determining credit quality (X14) & 2 \\
& Validity Period of Giving Stimulus & 2 \\
& (X15) & 4 \\
Legal & Legal knowledge (X21) & \\
Awareness & Knowledge on legal contents (X22) & 4 \\
(X2) & Legal attitude (X23) & 3 \\
& Legal behavior pattern (X24) & 4 \\
Legal & Compliance (Y1) & 2 \\
Compliance & Identification(Y2) & 2 \\
(Y) & Internalization (Y3) & 2 \\
\hline
\end{tabular}

Table 2. Demographics of the Respondents

\begin{tabular}{|c|c|c|c|c|}
\hline No & MSME Area & Population & Samples & \\
\hline 1 & Kudus & 30,581 & 68 & \\
\hline 2 & Magelang & 11,014 & 25 & \\
\hline 3 & Purwokerto & 23,787 & 53 & \\
\hline 4 & Semarang & 38,544 & 86 & \\
\hline 5 & Solo & 34,220 & 76 & \\
\hline 6 & Tegal & 16,308 & 36 & \\
\hline 7 & Yogyakarta & 25,075 & 56 & \\
\hline Total & & 179,529 & & 400 \\
\hline
\end{tabular}

The research data were tested for validity and reliability. The validity test was conducted using Pearson Product Moment (r) correlation analysis. An indicator or item is said to be valid if the value of the correlation coefficient between the item score and the total item score is corrected by $r>0.30$ (Solimun et. al., 2018). The reliability test was carried out by measuring the coefficient (Cronbach's Alpha). The reliability value is seen from the Cronbach's alpha of each questionnaire. A questionnaire is said to be reliable if the value is $>0.60$ (Solimun et al., 2018).

After the data is declared valid and reliable, then the data is statistically analyzed using

13 Soerjono Soekanto, 1981 Kesadaran Hukum, and Kepatuhan Hukum, Rajawali, Jakarta hlm 50. 
the GSCA (Generated Structured Component Analysis) method. GSCA is component-based SEM variant or approach. The GSCA method was chosen because 1) the variables in this research are latent variables and 2) this research examines not only the relationship among variables but also among indicators.

\section{DISCUSSION AND ANALYSIS}

Fadhal ${ }^{14}$ argues that law is a collection of rules consisting of norms and sanctions to establish order in human relations so that security and order are maintained. According to Johannes ${ }^{15}$, law is a coercive regulation that regulates human behavior in society made by an authorized agency. Violation of this regulation results in actions with certain sanctions. Therefore, the issuance of Regulation Number 11/POJK.03/2020 needs to be reviewed to find out the impact of the determination of the policy.

Regulatory relaxation is the process of granting concessions on terms and conditions related to the application of certain laws. This paper will focus on relaxation of bank credit rules. The relaxation of these rules takes the form of loosening credit terms, both financial and nonfinancial, to facilitate bank debtors. In particular, the FSA Regulation No. 11/POJK.03/2020 concerning National Economic Stimulus will be reviewed as a Countercyclical Policy for the Impact of the Coronavirus Disease 2019 Outbreak and its Relation to Legal Awareness and Legal Compliance. This regulation refers to Law of the Republic of Indonesia Number 2 Year 2020 concerning Stipulation of Government Regulation in Lieu of Law Number 1 Year 2020 concerning State Financial Policy and Financial System Stability in Handling Covid-19 and/or in the Context of Facing Threats which Endanger the Stability of the National Economy and/ or the Financial System Becomes Law. The government's objective of providing relaxation is

14 Fadhal Fathurrohman, 2020, Siaga HAM Sebagai Media Pendayagunaan Masyarakat Dalam Penegakan Hukum Guna Memaksimalkan Perlindungan Hak Asasi Manusia," ANTOLOGI ESAI HUKUM DAN HAM Afiliasi Hukum dan HAM dalam Mewujudkan Perlindungan Hak Asasi Masyarakat Indonesia 1, hlm 39.

15 Johannes CTSimorangkirand Woerjono Sastropranoto 1962, Peladjaran Hukum Indonesia, Gunung Agung, hlm 7 . to prevent massive non-performing loans (NPLs) which in turn will have a systematic impact on the health of the banking system itself. The operational definition of Regulatory relaxation is the loosening of credit regulations and conditions, both financial and non-financial conditions, to facilitate banking customers. The government's objective of providing relaxation is that there will be no massive Non-Performing Loans (NPLs) which will ultimately have a systematic impact on the health of the banking system itself.

The word awareness derives from the word aware which means to be aware, feel, know or understand. To be aware means to know, to realize, to feel. Awareness means realization, a state of understanding what a person feels or experiences ${ }^{16}$. Legal awareness is often associated with law enforcement, law establishment, and legal effectiveness. Legal awareness is an abstract conception within humans, about the harmony between order and peace that is desired or appropriate. According to this definition, legal awareness is awareness of the values contained in humans about the law and public legal awareness in principle also questions aspects of law enforcement. In addition, the form of legal awareness as a bridge connects legal regulations with the legal behavior of community members. According to Suharso Retnoningsih ${ }^{16}$ Legal awareness is a sincere state that arises from the conscienceinrecognizingandpracticingsomething in accordance with the guidance contained in it, which arises from the deepest conscience and soul of humans as individuals or communities to carry out the messages contained in the law. ${ }^{17}$ This is in line with research conducted by Apriandini which found that a community which instills legal values will form legal awareness through the legal values so that an attitude of obedience arises in the community. ${ }^{18}$ Based on this, the FSA Regulation Number 11/POJK.03/2020 can have an impact on legal awareness in the community

16 Suharso Retnoningsih, 2005, Kamus Besar Bahasa Indonesia, Cetakan Pertama, Widya Karya, Semarang, hlm 20-21.

17 Beni Ahmad Saebeni, 2006, Sosiologi Hukum, Pustaka Setia, Bandung, hlm. 197.

18 Apriandhini, M., Santi, Y., \& Widhi, E. N., 2021. KESADARAN DAN KEPATUHAN HUKUM PEKERJA TERHADAP PENERAPAN PROTOKOL KESEHATAN MASA PANDEMI COVID-19 DI UPBJJ UT SAMARINDA. HUMAYA: Jurnal Hukum, Humaniora, Masyarakat, dan Budaya, 1(1), hlm 75-84. 
First, the stage of legal knowledge about a person's knowledge of certain behaviors regulated by written law, namely what is prohibited or what is allowed. Second, the stage of legal understanding is the information that a person has regarding the contents of legal regulations (written), regarding the contents, objectives, and benefits of the regulations. Third, the stage of legal attitude is the tendency to accept or reject the law because of the appreciation or belief that the law is beneficial or not beneficial for human life. The higher the level of customer's understanding of regulations, the better the legal awareness in implementing credit payment obligations ${ }^{19}$. This is in line with Ningtias' research ${ }^{20}$ which states that people will obey the rules because they are afraid of sanctions and they obey the rules because of their social status. Therefore, legal compliance will reflect the behavior of the community.

Legal compliance is the attitude or behavior of a person or a community towards legal values which are upheld in living together and which are manifested in the form of behavior that is truly obedient to legal values. Legal compliance is compliance with values that exist in humans regarding existing law or about law which is expectedtoexist ${ }^{14}$.Sociologically,legalcompliance is the state of a member of community who is obedient to one rule (law) that applies. According to Soerjono ${ }^{21}$ and Salman (1989), there are 3 (three) factors that cause members of community to obey the law, they are: a) Compliance, b) Identification, c) Internalization. Therefore, with the stipulation of the FSA regulation Number 11/POJK.03/2020, the public and related institutions can comply.

19 CHORIDAH, LUTFIANA, 2017, Pengaruh Pemahaman Peraturan Dan Kesadaran Hukum Terhadap Kepatuhan Wajib Pajak Muslim Dalam Membayar Pajak Bumi Dan Bangunan (Studi Kasus Di Dukuh Payaman Desa Payaman Mejobo Kudus). Diss. STAIN KUDUS, hlm 32-33.

2o Ningtias, A. P2021. PENGARUH PENGETAHUAN HUKUM DAN KESADARAN HUKUM TERHADAP KEPATUHAN HUKUM WARGA KOTA JAMBI DALAM MENERAPKAN PROTOKOL KESEHATAN COVID-19 (Doctoral dissertation, UNIVERSITAS JAMBI). Hlm 50

21 Soejono Soekanto, 2018, Faktor-Faktor yang mempengaruhi Penegakan Hukum, Depok, hlm 19-20
According to Soejono Soekanto ${ }^{22}$, the nature of legal compliance has 3 (three) factors that cause citizens to obey the law, namely:

a. Fulfillment

Compliance is based on the expectation of a reward and an attempt to avoid penalties or sanctions that may be imposed if a person violates the provisions of the law. This compliance is not at all based on belief in the objectives of the law in question and is more based on the control of the authorities. As a result, legal compliance will exist if there is strict supervision of the implementation of principles of the law.

b. Identification

This occurs when compliance with the legal rules exists not because of its intrinsic value, but to maintain group membership and there is good relationship with those authorized to enforce the legal rules. The attraction of compliance is the advantage that results from the relationship so that compliance depends on the pros and cons of the interaction.

c. Internalization

At this stage, a person obeys the legal rules because in essence obedience has a reward. The contents of these rules follow the values of the concerned, or because the person changes the values that were originally adopted. The result of this process is conformity based on intrinsic motivation. The central point of the power of this process is one's belief in the purpose of the rule in question, regardless of its influence or value on the group or the authorities or supervision. This stage is the highest level of compliance, where compliance arises because the applicable law is below the values adopted ${ }^{15}$.

Legal compliance is a manifestation of human attitudes that do or do not violate the applicable rules. Obedience to the law is not obtained if a person does not have legal awareness. Legal awareness and legal compliance are closely related, but legal awareness is the primary form, while legal compliance can only be obtained if a person understands the law.

22 Soerjono Soekanto, 2018, Faktor-Faktor Yang Mempengaruhi Penegakan Hukum. Depok, Rajawali Press, 22-23. 
Research conducted by Ilyas found that legal norms must be formulated in clear sentences and do not cause multiple interpretations, because they can lead to legal disobedience and uncertainty among the public ${ }^{23}$.

According to Utrecht $^{24}$ in his book entitled Pengantar Hukum Tata Usaha Negara (Introduction to State Administrative Law), there are several things that cause a person to obey the law First, a person feels that the regulation is perceived as law. This means that they really have interests in the enactment of the regulation or law. One does have to accept it, so that there is a sense of peace. This means that people choose to obey the law so as not to experience many difficulties in their lives. Second, the individual or society wants it, because in general people only feel the existence of the law if the existing legal regulations limit the extent of their interests. Furthermore, a person obeys the law because of social coercion (sanctions). People generally feel embarrassed or worried about being accused of being partners when people break the law.

According to Utrecht's view, the things that can make a person obey the law are inseparable from their own interests and the law is seen as a weapon to protect one's interests.

The Effect of Legal Substance on Legal Compliance. The researchers have not found any research that examines legal substance in relation to legal awareness and legal compliance. This paper will focus on the relaxation of bank credit rules. This rule relaxation takes the form of loosening credit terms, both financial and nonfinancial, to facilitate bank debtors. This rule relaxation is expected to reduce the impact of declining debtor performance, especially MSMEs, which can increase the risk of non-performing loans. The government's objective of providing relaxation is to prevent massive non-performing loans (NPLs) which in turn will have a systematic impact on the health of the banking system itself.

Increased credit risk has the potential to disrupt banking performance and financial system stability that can affect economic growth, therefore countercyclical policy is needed. Countercyclical policy of the impact of the spread of the COVID-19 disease is aimed at encouraging banking performance, especially the intermediation function, maintaining financial system stability, and supporting economic growth. All of these is done by giving special treatment to bank credit or financing with a certain amount and restructuring credit or financing for affected debtors, including micro, small and medium enterprise debtors.

Based on the description above, the first hypothesis in this research is formulated as follows:

H1: Legal Substance has a significant effect on Legal Compliance

The Effect of Legal Awareness on Legal Compliance. The researchers have not found any research that examines the legal substance in relation to legal awareness and legal compliance. Legal awareness is awareness of values that exist in humans regarding existing law or law which is expected to exist ${ }^{14}$. The purpose of the issuance of this regulation is to provide credit relaxation for customers affected by Covid-19. However, the government did not further define the relaxation of bank credit in question. Even the government returned this definition to the policies of each bank. The legal definition of bank credit relaxation is the loosening of credit terms, both financial and nonfinancial, to facilitate banking customers. Based on the description above, the second hypothesis in this research is formulated as follows:

$\mathrm{H} 2$ : Legal Awareness has a significant effect on Legal Compliance

This research measured three variables, namely Legal Substance (X1), Legal Awareness (X2) and Legal Compliance (Y). Ten statement items measured the Legal Substance variable (X1). Fifteen statement items measured the Legal Awareness variable (X2). Then the Legal Compliance variable (Y) was measured by six statement items. Table 3 shows the results of the complete validity test.

23 Abudzar, M., \& Ilyas, M. A. 2019, Pendampingan Kepatuhan Dan Kesadaran Hukum Bagi Masyarakat Desa Dusun Sawah, hlm 19-20.

24 Elien Utrecht, 1955, Pengantar Dalam Hukum Indonesia (Penerbitan dan Balai Buku Indonesia, hlm 35-37. 
Table 3. Validity and Reliability Test

\begin{tabular}{|c|c|c|c|}
\hline Variables & Item & $\begin{array}{l}\text { Pearson } \\
\text { Correlation }\end{array}$ & $\begin{array}{l}\text { Cronbach } \\
\text { Alpha }\end{array}$ \\
\hline \multirow{10}{*}{$\begin{array}{l}\text { Legal Substance } \\
\text { (X1) }\end{array}$} & X111 & 0,570 & \multirow{10}{*}{0,759} \\
\hline & X112 & 0,439 & \\
\hline & X121 & 0,381 & \\
\hline & $\mathrm{X} 122$ & 0,366 & \\
\hline & X131 & 0,413 & \\
\hline & X132 & 0,380 & \\
\hline & X141 & 0,430 & \\
\hline & X142 & 0,509 & \\
\hline & X151 & 0,361 & \\
\hline & $\mathrm{X} 152$ & 0,369 & \\
\hline \multirow{15}{*}{$\begin{array}{l}\text { Legal Awareness } \\
\text { (X2) }\end{array}$} & $\mathrm{X} 211$ & 0,403 & \multirow{15}{*}{0,809} \\
\hline & $\mathrm{X} 212$ & 0,325 & \\
\hline & X213 & 0,419 & \\
\hline & X214 & 0,413 & \\
\hline & X221 & 0,356 & \\
\hline & X222 & 0,554 & \\
\hline & $\mathrm{X} 223$ & 0,405 & \\
\hline & X224 & 0,434 & \\
\hline & X231 & 0,523 & \\
\hline & X232 & 0,351 & \\
\hline & X233 & 0,511 & \\
\hline & X241 & 0,506 & \\
\hline & $\mathrm{X} 242$ & 0,436 & \\
\hline & X243 & 0,326 & \\
\hline & X244 & 0,354 & \\
\hline \multirow{6}{*}{$\begin{array}{l}\text { Legal } \\
\text { Compliance (Y) }\end{array}$} & Y11 & 0,526 & \multirow{6}{*}{0,763} \\
\hline & Y12 & 0,479 & \\
\hline & $\mathrm{Y} 21$ & 0,631 & \\
\hline & Y22 & 0,438 & \\
\hline & Y31 & 0,489 & \\
\hline & Y32 & 0,471 & \\
\hline
\end{tabular}

Table 3 shows that all items are declared valid because they have a Pearson correlation value $>0.3$. Also, it can be seen that all variables are declared reliable. This is indicated by the Cronbach Alpha value which is greater than 0.6.

The data in this research were analyzed descriptively. The descriptive analysis used consists of the minimum, maximum and average values of each indicator. Table 4 shows the results of the descriptive analysis of each research variable.

Table 4. Descriptive Analysis of the Variables

\begin{tabular}{|c|c|c|c|c|}
\hline Variables & Indicators & Min & $\operatorname{Max}$ & Average \\
\hline \multirow{5}{*}{$\begin{array}{l}\text { Legal } \\
\text { Substance } \\
\text { (X1) }\end{array}$} & $\begin{array}{l}\text { Restructuring credit or } \\
\text { financing }(\mathrm{X} 11)\end{array}$ & 2.00 & 5.00 & 3.45 \\
\hline & $\begin{array}{l}\text { Providing credit or } \\
\text { financing (X12) }\end{array}$ & 2.00 & 5.00 & 3.36 \\
\hline & $\begin{array}{l}\text { Providing other new } \\
\text { funds (X13) }\end{array}$ & 2.00 & 5.00 & 3.39 \\
\hline & $\begin{array}{l}\text { Determination of credit } \\
\text { quality (X14) }\end{array}$ & 2.00 & 5.00 & 3.37 \\
\hline & $\begin{array}{l}\text { Validity Period of } \\
\text { Giving Stimulus (X15) }\end{array}$ & 2.00 & 5.00 & 3.35 \\
\hline \multirow{4}{*}{$\begin{array}{l}\text { Legal } \\
\text { Awareness } \\
(\mathrm{X} 2)\end{array}$} & Legal knowledge (X21) & 2.00 & 4.75 & 3.35 \\
\hline & $\begin{array}{l}\text { Knowledge on legal } \\
\text { contents (X22) }\end{array}$ & 2.25 & 4.75 & 3.41 \\
\hline & Legal attitude (X23) & 2.00 & 5.00 & 3.35 \\
\hline & $\begin{array}{l}\text { Legal behavior pattern } \\
\text { (X24) }\end{array}$ & 2.00 & 4.50 & 3.39 \\
\hline \multirow{3}{*}{$\begin{array}{l}\text { Legal } \\
\text { Compliance } \\
\text { (Y) }\end{array}$} & Compliance (Y1) & 2.00 & 5.00 & 3.43 \\
\hline & Identification (Y2) & 2.00 & 5.00 & 3.36 \\
\hline & Internalization (Y3) & 2.00 & 5.00 & 3.34 \\
\hline
\end{tabular}

The research model was also analyzed using the GSCA approach using GeSCA software. The feasibility of the model obtained from the analysis results can be determined using several criteria, as presented in Table 5 below.

Table 5. Goodness of Fit Model

\begin{tabular}{|c|c|c|c|c|}
\hline No. & Fit Model & Measure & Std.Error & P-Value \\
\hline 1 & FIT & 0.482 & 0.010 & $<0,001$ \\
\hline 2 & $\begin{array}{l}\text { Adjusted FIT } \\
\text { (AFIT) }\end{array}$ & 0.480 & 0.010 & $<0,001$ \\
\hline 3 & GFI & 0.986 & 0.001 & $<0,001$ \\
\hline 4 & $\begin{array}{l}\text { Standardized Root } \\
\text { Mean Square } \\
\text { (SRMR) }\end{array}$ & 0.065 & 0.008 & $<0,001$ \\
\hline 5 & FIT_M & 0.559 & 0.011 & $<0,001$ \\
\hline 6 & FIT $S$ & $\underline{0.174}$ & $\underline{0.018}$ & $\leq 0,001$ \\
\hline
\end{tabular}

Table 5 is a summary of the Goodness of Fit obtained from the output of the GeSCAapplication. Table 5 shows that of the six model criteria, this research model is declared feasible. FIT represents the total variance of all variables that can be explained by the model, with values ranging from 0 to 1 . The closer the value to $1(100 \%)$, the better the model. In Table 5, FIT is 0.482 with p-value $<0.001$, which means that the model can explain the variables of Legal Substance (X1), Legal 
Awareness (X2) and Legal Compliance (Y) for $48.2 \%$ and the rest is explained by other variables that have not been into the model as well as the error component. With p-value $<0.001$, then FIT is said to be significant, not equal to zero, meaning that the model is widely applicable (generally).

In addition, Adjusted of FIT (AFIT) shows a value of 0.480 . AFIT is the corrected model accuracy. From the result of the identification of the AFIT value, it can be concluded that the model can explain all variables used with a p-value $<0.001$ of $48.0 \%$. In addition, the Goodness of Fit Index (GFI) value is 0.986. Basically, GFI describes the overall level of model fit which is calculated from the square of the predicted residual model compared to the actual data. If the GFI value is more than 0.90 , it can be concluded that the model has a good fit. The identification result is even close to 1 , so it can be concluded that the research model has a perfect fit.

The following section will explain the factor loading of each indicator on the variables it reflects, namely the amount of contribution of each indicator variable it reflects. This research used three variables. The following is a summary of the factor loading values as shown in Table 6 .

Table 6. Factor Loading Values (Outer Model)

\begin{tabular}{lcc}
\hline \multicolumn{1}{c}{ Variables } & Indicators & Factor Loading \\
\hline & X11 & 0.736 \\
& X12 & 0.787 \\
Legal Substance & X13 & 0.663 \\
(X1) & & \\
& X14 & 0.691 \\
& & \\
& X15 & 0.662 \\
Legal Awareness & X21 & 0.748 \\
(X2) & X23 & 0.752 \\
& X24 & 0.732 \\
& Y1 & 0.728 \\
Legal & Y2 & 0.819 \\
Compliance (Y) & Y3 & 0.816 \\
& & 0.818 \\
\hline
\end{tabular}

Table 6 shows that the five indicators can measure the variable of Legal Substance (X1) significantly. It is also seen that the four indicators significantly measured the variable of Legal Awareness (X2). Finally, the variable of Legal
Compliance (Y) was significantly measured by three indicators.

Hypothesis testing in this study was conducted on 2 relationships among the variables. The two relationships among the variables are the effect of legal substance on legal compliance and the effect of legal awareness on legal compliance. Table 7 below provides the results of hypothesis testing.

Table 7. Hypothesis Testing (Inner Model)

\begin{tabular}{lccccc}
\hline \multicolumn{2}{c}{ Variables } & $\begin{array}{c}\text { Path } \\
\text { Coef }\end{array}$ & Std. Error & P-Value & Results \\
\hline X1 à & Y & 0.480 & 0.035 & $<0.001$ & Accepted \\
X2 à & Y & 0.474 & 0.040 & $<0.001$ & Accepted \\
\hline
\end{tabular}

In addition, the results of hypothesis testing can also be presented with path analysis in the following figure.

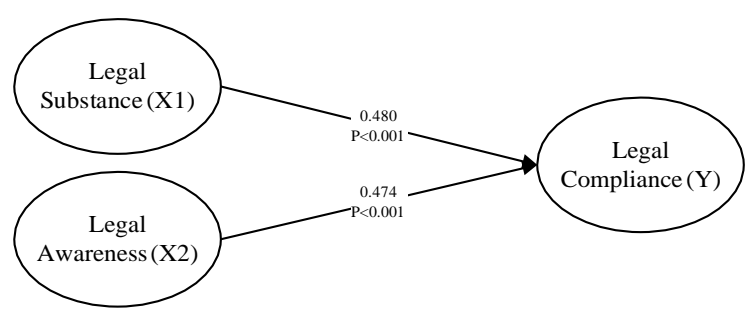

Figure 2. The Path Analysis

Based on Table 7 and Figure 2, the results of testing the hypothesis $\mathrm{H} 1$ show that the path coefficient is 0.480 and p-value $<0.001$ (significant); therefore, the hypothesis is accepted. The path coefficient is positive, meaning that the better the Legal Substance (X1), the better the Legal Compliance (Y1). Furthermore, the results of hypothesis testing for $\mathrm{H} 2$ show that the path coefficient is 0.474 and p-value $<0.001$ (significant); therefore, the hypothesis is accepted. The path coefficient is positive, meaning that the better the Legal Awareness (X2), the better the Legal Compliance (Y1).

Eachvariableisreflectedbyseveralindicators. Table 7 and Figure 2 show the contribution of each indicator to the reflected variable. The indicator that has the most significant contribution in measuring the perception of MSME actors on legal substance is the provision of credit or financing. This shows that MSMEs hope to be given credit or financing to survive the COVID-19 pandemic. However, if this cannot be realized, MSME actors 
expect a credit or financing restructuring to help to reduce the burden/obligation they have to pay in paying off credit. Later, the third priority for MSMEs which are Bank Mandiri customers is the determination of the quality of new loans and the provision of other new funds. The reason is, MSMEs need an injection of funds to survive in the midst of the Covid-19 pandemic. The validity period of the stimulus is not considered by MSME actors.

The second variable is Legal Awareness. Based on the results of the analysis, it can be seen that the legal awareness of MSME actors is best reflected in knowledge on the contents of the law. Then, the second aspect that most accurately reflects the legal awareness of MSME actors is the aspect of legal knowledge. Aspects of legal attitudes and legal behavior patterns are the third and fourth aspects that most accurately reflect legal awareness. On average, MSME actors' knowledge on legal content is relatively high. This is indicated by the average value which is greater than 3.00 (Table 4). In addition, the legal attitude and legal behavior patterns of MSME actors are also quite good.

Legal compliance of MSME actors is reflected in three aspects, namely compliance, identification and internalization. MSME customer compliance is at interval of 2.00 to 5.00. This shows that there are customers who are disobedient, and there are customers who are very compliant as well. However, on average, MSME actors are quite compliant with applicable laws (indicated by an average value which is greater than 0.3). The identification aspect is at interval of 2.00 to 5.00. This shows the diversity of MSME actors in identifying the applicable laws. However, on average, most MSME actors can identify the law well. This occurs when compliance with legal rules exists not because of its intrinsic value, but to maintain group membership and there is good relation with those authorized to enforce the legal rules. The attraction of compliance is the advantage of this relationship. Therefore, compliance depends on the pros and cons of the interaction. Similar to the previous aspect, the internalization aspect is also at interval of 2.00 to 5.00. This shows the diversity of responses from MSME actors. On average, the internalization aspect is relatively high, which is indicated by the average value which is greater than 0.3 . At this stage, a person obeys legal rules because in essence obedience has a reward. The contents of these rules follow the values of the concerned, or because the person changes the values that were originally adopted. The result of this process is conformity based on intrinsic motivation. The central point of the power of this process is one's belief in the purpose of the rule in question, regardless of its influence or value on the group or the authorities or supervision. This stage is the highest level of compliance, where obedience arises because the applicable law is in accordance with the values adopted.

Based on the results of the analysis, the path coefficient of the effect of legal substance on legal compliance is 0.480 with p-value $<0.001$. Because the $\mathrm{p}$-value $<0.05$, legal substance has a significant effect on legal compliance. Given the positive path coefficient, the relationship between the two is comparable. This means that the better the legal substance, the better the legal compliance. If it is associated with the inner PLS model, it shows that the better the credit or financing restructuring, the provision of credit or financing, the provision of other new funds, the determination of credit quality and the validity period of the stimulus, the higher the Compliance, Identification and Internalization.

Based on the results of the analysis, the path coefficient of the influence of legal awareness on legal compliance is 0.474 with p-value $<0.001$. Because p-value $<0.05$, legal awareness has a significant effect on legal compliance. Given the positive path coefficient, the relationship between the two is comparable. This means that the better the legal awareness, the better the legal compliance. If it is associated with the inner PLS model, it shows that the higher the legal knowledge, knowledge on legal content, legal attitudes and legal behavior patterns, the higher the compliance, identification and internalization.

The results of this research provide information that one of the efforts to improve legal compliance is through increasing legal awareness, especially the aspect of knowledge on legal content. The priority of increasing the aspect of knowledge on the content of the law is based on the result of the analysis that this indicator is the most important or dominant as a measure of legal awareness. 


\section{CONCLUSION}

This research was conducted at Bank Mandiri, especially in the Regional Offices of Central Java and Yogyakarta. This research only involved 400 respondents from 179,529 MSME customers of Bank Mandiri. This research also only involved three variables, namely legal substance, legal awareness and legal compliance.

Based on the results of the analysis, it can be concluded that legal substance was measured significantly through five indicators, namely restructuring of credit or financing, provision of credit or financing, provision of other new funds, determination of credit quality and the validity period of the provision of stimulus. Legal awareness was significantly measured by four indicators, namely legal knowledge, knowledge on legal content, legal attitudes and legal behavior patterns. Furthermore, legal compliance was significantly measured by three indicators, namely Compliance, Identification and Internalization. The results of the analysis also show that legal substance and legal awareness have a significant effect on legal compliance.

\section{SUGGESTION}

The suggestion of this research for Bank Mandiri is that Bank Mandiri can use the results of this research as a reference in policy making related to MSME customers of Bank Mandiri, especially in credit or financing restructuring, provision of credit or financing, provision of other new funds, determination of credit quality and the validity period of the provision of stimulus. Suggestions for other researchers are to involve more respondents and conduct research in other institutions or agencies. In addition, researchers can involve other variables related to law. Later, researchers can examine the three variables after the Covid-19 pandemic ends.

\section{BIBLIOGRAPHY}

Apriandhini, M., Santi, Y., \& Widhi, E. N. (2021). KESADARAN DAN KEPATUHAN HUKUM PEKERJA TERHADAP PENERAPAN PROTOKOL KESEHATAN MASA PANDEMI COVID-19 DI UPBJJ UT SAMARINDA. HUMAYA: Jurnal Hukum, Humaniora, Masyarakat, dan Budaya, 1(1), 75-84.
Abudzar, M., \& Ilyas, M. A. Pendampingan Kepatuhan Dan Kesadaran Hukum Bagi Masyarakat Desa Dusun Sawah.

Beni Ahmad Saebeni, "Sosiologi Hukum", Pustaka Setia, Bandung, (2006).

CHORIDAH, L. "Pengaruh Pemahaman Peraturan Dan Kesadaran Hukum Terhadap Kepatuhan Wajib Pajak Muslim Dalam Membayar Pajak Bumi Dan Bangunan (Studi Kasus Di Dukuh Payaman Desa Payaman Mejobo Kudus) (Doctoral dissertation, STAIN KUDUS)". (2017).

Fathurrohman, Fadhal. “'Siaga HAM' Sebagai Media Pendayagunaan Masyarakat Dalam Penegakan Hukum Guna Memaksimalkan Perlindungan Hak Asasi Manusia." ANTOLOGI ESAI HUKUM DAN HAM Afiliasi Hukum dan HAM dalam Mewujudkan Perlindungan Hak Asasi Masyarakat Indonesia 1 (2020): 39.

Fletcher, Adam, Kirsty McCulloch, Stuart D Baulk, and Drew Dawson. "Countermeasures to Driver Fatigue: A Review of Public Awareness Campaigns and Legal Approaches." Australian and New Zealand Journal of Public Health 29, no. 5 (2005): 471-476.

Klepper, Steven, Mark Mazur, and Daniel Nagin. "Expert Intermediaries and Legal Compliance: The Case of Tax Preparers." The Journal of Law and Economics 34, no. 1 (1991): 205-229.

Macura, Biljana, Francisco Zorondo-Rodríguez, Mar Grau-Satorras, Kathryn Demps, Marie Laval, Claude A Garcia, and Victoria ReyesGarcía. "Local Community Attitudes toward Forests Outside Protected Areas in India. Impact of Legal Awareness, Trust, and Participation." Ecology and society 16, no. 3 (2011).

Marwah, Marwah. "Relaksasi Kredit Perbankan Di Daerah Wisata Yang Tertimpa Bencana Alama." Jurisprudentie: Jurusan Ilmu Hukum Fakultas Syariah dan Hukum 6, no. 1 (2019): 125-134.

Nurhalimah, Siti. "Covid-19 Dan Hak Masyarakat Atas Kesehatan." SALAM: Jurnal Sosial dan Budaya Syar-i 7, no. 6 (2020): 543-554. 
Prodjodikoro, R Wirjono. Asas-Asas Hukum Perjanjian, Mandar Maju. Bandung, Hal. Vol. 3, 2003.

Retnoningsih, Suharso. Kamus Besar Bahasa Indonesia. Cetakan Pertama, Widya Karya, Semarang, 2005.

Rosana, Ellya. "Kepatuhan Hukum Sebagai Wujud Kesadaran Hukum Masyarakat." Jurnal Tapis: Jurnal Teropong Aspirasi Politik Islam 10, no. 1 (2014): 61-84.

Satradinata, Dhevi Nayasari, and Bambang Eko Muljono. "Analisis Hukum Relaksasi Kreadit Saat Pandemi Corona Dengan Kelonggaran Kredit Berdasarkan Peraturan Otoritas Jasa Keuangan Nomor 11/POJK. 03/2020." Jurnal Sains Sosio Humaniora 4, no. 2 (2020): 613-620.

Schofield, Paul. "Following the Law Because It's the Law: Obedience, Bootstrapping, and Practical Reason." Philosophical Explorations 21, no. 3 (2018): 400-411.

Simorangkir, Johannes $\mathrm{C} \mathrm{T}$, and Woerjono Sastropranoto. Peladjaran Hukum Indonesia. Gunung Agung, 1962.

Soekanto, Soerjono. "Faktor-Faktor Yang Mempengaruhi Penegakan Hukum. Depok." Rajawali Press, 2018.

Treviño, Linda Klebe, Gary R Weaver, David G Gibson, and Barbara Ley Toffler. "Managing Ethics and Legal Compliance: What Works and What Hurts." California management review 41, no. 2 (1999): 131-151.

Utrecht, Elien. Pengantar Dalam Hukum Indonesia. Penerbitan dan Balai Buku Indonesia, 1955.

Waluyo, Bambang. "Penelitian Hukum Dalam Praktek" (2008). 